1.01

Kornelija Ajlec*

\title{
Vloga Unrre pri oskrbi in repatriaciji jugoslovanskih razseljenih oseb v Italiji (1945-1947)**
}

\section{IZVLEČEK}

S kritično analizo arhivskih virov, ki jih hrani Arhiv Organizacije združenih narodov v $\mathrm{New}$ Yorku, in s pomočjo literature clanek prikazuje preskrbo in repatriacijo jugoslovanskih razseljenih oseb iz Italije v Jugoslavijo ob posredniški pomoči Uprave združenih narodov za pomoč in obnovo - UNRRA (United Nations Relief and Rehabilitation Administration). Jugoslavija je zahtevala repatriacijo razseljenih oseb neposredno po koncu spopadov, a mnoge so se vračale še v letih 1946 in 1947, precejšnje število pa je emigriralo v tretje države.

Ključne besede: begunci, Italija, Jugoslavija, UNRRA, repatriacija

ABSTRACT

\section{THE ROLE OF UNRRA IN SUPPLYING AND REPATRIATING THE YUGOSLAVIANS DISPLACED IN ITALY (1945-1947)}

Through a critical analysis of the relevant literature and archival sources kept in the Archives of the United Nations in New York, the article outlines the provision of supplies and repatriation of the displaced Yugoslavs from Italy back to Yugoslavia with the mediation assistance of the United Nations Relief and Rehabilitation Administration (UNRRA). Immediately after the end of the war, Yugoslavia demanded the repatriation of the displaced

\footnotetext{
* Dr., izr. prof., Oddelek za zgodovino, Filozofska fakulteta, Univerza v Ljubljani, Aškerčeva 2, SI-1000 Ljubljana; kornelija.ajlec@ff.uni-lj.si

** Članek je nastal kot del projekta $\gg$ Begunci - nikoli dokončana zgodba (J6-8249)《 in raziskovalnega programa $\gg$ Slovenska zgodovina (P6-0235) «, ki ju financira ARRS, ter s podporo Fulbrightovega štipendijskega sklada.
} 
persons. However, people kept returning until as late as 1946 and 1947, while many of them emigrated to other countries.

Keywords: refugees, Italy, Yugoslavia, UNRRA, repatriation

\section{Uvod}

Ob ustanovnem kongresu Uprave združenih narodov za pomoč in obnovo (United Nations Relief and Rehabilitation Administration - UNRRA) so se države ustanoviteljice, med njimi tudi Jugoslavija, posvečale vprašanjem repatriacije razseljenih oseb. ${ }^{1}$ Med prvim zasedanjem Unrrinega sveta v Atlantic Cityju januarja 1944 je bila sprejeta Resolucija št. 10, ki je določala obveznosti Unrre do beguncev ali, če uporabimo izraz, ki se je tedaj začel uveljavljati, razseljenih oseb. $V$ njej je bilo med drugim zapisano, da bo UNRRA glavna izvajalka repatriacijskih procesov ob pomoči držav gostiteljic in držav sprejemnic. ${ }^{2} S$ podpisom sporazuma med Unrro in Italijo marca 1945, s katerim je bila ustanovljena Unrrina italijanska misija, je k resoluciji pristopila tudi italijanska vlada. ${ }^{3}$

Ker pa je ustanovni sporazum Unrre podpisal predstavnik jugoslovanske begunske vlade kralja Petra II., se je morala k resoluciji zaradi političnih sprememb neposredno po koncu vojne zavezati tudi nova vlada Jugoslavije pod vodstvom Josipa Broza Tita. Ob ustanovitvi Unrrine jugoslovanske misije marca 1945 je bil tako podpisan tudi dvostranski sporazum med Demokratično federativno Jugoslavijo (DFJ) in Unrro. ${ }^{4}$ $\mathrm{Z}$ ustanovitvijo jugoslovanske misije je nastala tudi državna komisija vojnih ujetnikov, prisilno odpeljanih delavcev, obsojencev in drugih, ki jih je okupator odpeljal iz Jugoslavije. Komisija je delovala v okviru Ministrstva za socialno politiko DFJ, njen izvršni odbor pa so sestavljale jugoslovanske delegacije za repatriacijo iz tujine pri jugoslovanskih predstavništvih $\mathrm{v}$ tujini. ${ }^{5}$ Jugoslovanske delegacije v tujini so imele številne naloge, povezane z razseljenimi osebami in repatriacijo. Med drugim so morale ščititi interese

1 Poenoten izraz $\gg$ razseljene osebe $\ll$ v času druge svetovne vojne prvi uporabljajo v SHAEF (Supreme Headquarters Allied Expeditionary Force). Med razseljene osebe uvrstijo evakuirance, vojaške ali politične begunce, politične ujetnike, prisilne ali prostovoljne delavce, prisilne delavce $\mathrm{v}$ nacistični organizaciji Todt in prisilne mobilizirance $\mathrm{v}$ nemško ali italijansko vojsko, pregnance, nasilno preseljene in naseljene osebe, internirance, nekdanje vojne ujetnike in osebe brez državljanstva. Več v Mark Wyman, DPs. Europe's Displaced Persons, 1945-51 (Ithaca, Cornell: University Press, 1998), 25.

2 A Compilation of the Resolutions on Policy. First and Second Sessions of the UNRRA Council, 2, Resolutions on Policy (Washington D. C.: United Nations Relief and Rehabilitation Administration, 1944), 21-23. Dostopno na: Hathitrust.org, https://hdl.handle.net/2027/mdp.39015063799061, pridobljeno avgusta 2020.

3 George Woodbridge, UNRRA. The History of the United Nations Relief and Rehabilitation Administration, 3 (New York: Columbia University Press, 1950), 296.

4 Več o podpisu sporazuma z vlado DFJ in ustanovitvi Unrrine jugoslovanske misije Kornelija Ajlec, »UNRRA v Jugoslaviji in Sloveniji,« Prispevki za novejšo zgodovino 53, št. 2 (2013): 79-99.

5 Tatjana Čepič, »Oris poteka repatriacije v letu 1945, « Kronika, 33, št. 2-3 (1985): 232-36. Jure Gombač, »K politiki povratnih migracij po drugi svetovni vojni, «v: Spet doma? Povratne migracije med politiko, prakso in teorijo, ur. Marina Lukšič Hacin (Ljubljana, Založba ZRC, 2006), 16. 
Jugoslavije, po jugoslovanskih vojaških misijah so morale vzdrževati zvezo z zavezniškimi vojnimi oblastmi, z jugoslovanskimi konzularnimi predstavništvi so morale reševati vprašanja ugotavljanja nacionalne pripadnosti repatriirancev in preverjati njihove dokumente, pravočasno obveščati štabe za repatriacijo o prihodu repatriacijskih konvojev, v soglasju z Unrro in zavezniškimi vojnimi oblastmi so vodile notranjo organizacijo taborišč in njihovih odborov, dvakrat mesečno pa so pošiljale poročila državni komisiji o svojem delu, stanju v taboriščih in gibanju repatriirancev. ${ }^{6}$ Pravilnik državne komisije je tudi jasno določal, kdo so repatriiranci. To so bili jugoslovanski državljani, ki so se ob osvoboditvi nahajali v tujini zaradi posledic vojne kot vojaki nekdanje kraljevine Jugoslavije v nemškem in italijanskem ujetništvu, prisilno odpeljani delavci, politični pregnanci, vse prebivalstvo, ki je bilo pregnano s svojih domov, in vsi tisti, ki so bili prisiljeni oditi na delo v Nemčijo ali na področja, ki jih je okupirala Nemčija. ${ }^{7}$

Ocenjuje se, da je bilo 30. septembra 1945 med razseljenimi osebami več kot 100.000 Jugoslovanov. ${ }^{8}$ Decembra tega leta je UNRRA skrbela za skupno 41.000 posameznikov jugoslovanske narodnosti, medtem ko je do junija 1947 število padlo na 17.000. ${ }^{9}$ A podatki o oskrbi Unrre ne obsegajo celega števila razseljenih oseb jugoslovanske narodnosti, zato moramo nekoliko bolj natančno statistiko iskati drugje. Medvladni odbor za begunce (Intergovernmental Committee for Refugees - IGCR) ${ }^{10}$ je ocenil, da je bilo maja 1946 v zahodni Evropi 130.000 razseljenih Jugoslovanov, kar 125.000 od teh naj se ne bi želelo vrniti v domovino. ${ }^{11}$ Velik del teh razseljenih oseb predstavljajo tisti, ki so migrirali šele po vojni, precejšen delež pa odpade na tiste, ki se še niso vrnili domov. Pot konfinirancev, internirancev, zapornikov in beguncev iz Jugoslavije v Italiji je bila zapletena in dolga. Med njimi so le begunci prišli v Italijo šele po njeni kapitulaciji in le povojni politični pribežniki po osvoboditvi Jugoslavije. Vsi ostali so se v Italiji nastanili že pred vojno ali v prvih letih vojne.

\section{Taborišča v Italiji}

S kapitulacijo Italije in prodiranjem zaveznikov proti severu Apeninskega polotoka so slednji osvobajali tudi številne konfinirance in zapornike. Osvobojence so zavezniki najprej zadržali na krajih osvoboditve, nato pa so za njih začeli ustanavljati

6 Gombač, $\gg$ K politiki povratnih migracij, $\ll 16$.

7 Čepič, $\gg$ Oris poteka repatriacije v letu $1945, \ll 232$.

8 Malcolm J. Proudfoot, European Refugees 1939-1952. A Study in Forced Population Movement, (Evanston: Northwestern University Press, 1956), 238, 239.

9 Woodbridge, UNRRA, 423.

10 IGCR je bil ustanovljen na evianski konferenci, ki je potekala od 6. do 15. julija 1938 v francoskem Evianu. Njegovo delovanje se je med drugim dotikalo beguncev, ki so zapustili svojo državo, a se še niso stalno naselili v drugi državi. Kasnejša literatura ga ni ocenjevala kot posebno uspešnega. Več: Decisions Taken at the Evian Conference on Jewish Refugees, July 1938, Yad Vashem The World Holocaust Remembrance Center, pridobljeno avgusta 2020, https:// www.yadvashem.org/docs/evian-conference-decisions.html. Ronnie S. Landau, The Nazi Holocaust. It's History and Meaning (New York: I. B. Tauris, 2006), 137. Jacques Vernant, The Refugee in the Post-War World, (New Haven: Yale University Press, 1956), 27.

11 Vernant, The Refugee in the Post-War World, 88. 
številna begunska taborišča, med katerimi sta verjetno bolj znani Cinecitta pri Rimu in Ferramonti di Tarso v Kalabriji. V Apuliji so ustanovili tri večja nastanitvena taborišča, kjer so večinski delež vsaj do prve polovice leta 1945 predstavljali Jugoslovani, in sicer Santa Maria al Bagno, Santa Maria di Leuca in Santa Cesarea. V podporo so delovala še manjša prehodna taborišča, kot sta bili Carbonara pri Bariju in Tuturano južno od Brindisija. S pomočjo teh taborišč je v letih 1944 in 1945 iskalo pot na varno skoraj 40.000 dalmatinskih beguncev in drugih Jugoslovanov. Večji del je nadaljeval pot $\mathrm{v}$ podobna begunska taborišča $\mathrm{v}$ Egiptu, približno 7.000 pa jih je ostalo $\mathrm{v}$ Italiji do repatriacije v prvi polovici leta $1945 .{ }^{12}$ Že ob prihodu prvih dalmatinskih beguncev $\mathrm{v}$ prehodno taborišče Carbonara so se ti tam srečali s številnimi osvobojenci, ki so zaveznike prosili, da jim omogočijo pridružitev Narodnoosvobodilni vojski Jugoslavije (NOVJ). V Bariju, kjer je od oktobra 1943 domovala vojaška misija NOVJ, so kmalu ustanovili prve prekomorske brigade, s katerimi so se ti osvobojenci vrnili v domovino.

Omenjena taborišča so bila prizorišče številnih ideoloških sporov med podporniki kralja Petra II. in njegove begunske vlade ter podporniki partizanov in nove porajajoče se komunistično usmerjene Titove Jugoslavije. Osvobojenci in razseljene osebe so se delili na rojaliste in partizane. Največ pritožb je prihajalo od partizanov, kjer so govorili o t. i. »četniški reakciji «, kot so v dokumentih in spominski literaturi poimenovali novačenje osvobojencev in beguncev v vrste kraljeve vojske v begunstvu. Prav tako so se privrženci partizanov pritoževali, da imajo rojalisti v primerjavi z njimi večje ugodnosti v begunskih taboriščih. Ko je zavezniška vojska, pretežno britanska, marca 1945 prepustila administracijo taborišč Unrri, so ti ideološki spori ves čas spremljali njeno delovanje $\mathrm{v}$ navezavi $\mathrm{z}$ jugoslovanskimi razseljenimi osebami, ki je bilo glede na že omenjeno Resolucijo št. $10 \mathrm{v}$ precejšni meri usmerjeno v njihovo repatriacijo. ${ }^{13}$

\section{Vrnitev v domovino?}

Po številnih ideoloških zapletih je bilo pričakovati, da se v Jugoslavijo ne bodo vrnile vse razseljene osebe. Večina tistih razseljenih oseb, ki so ostale v Italiji, je bila že prej ločena od podpornikov nove vlade, saj je štab zavezniške vojske na Bližnjem vzhodu (Allied Force Head Quarters AFHQ in the Middle East) že 10. novembra 1943 predlagal, da bi gibanje jugoslovanskih osvobojencev in kasneje evakuiranih beguncev omejili na taborišča, tu pa bi podpornike kraljeve begunske vlade in partizanov ločili. To je bilo sicer težje udejanjiti, kljub temu pa so večino podpornikov kraljeve vlade vendarle ločili in jih namestili predvsem $\mathrm{v}$ taborišče Arnesano pa tudi v druga manjša taborišča v bližini Lecceja ter v taborišče Pisticci v provinci Matera. ${ }^{14}$ Večji del

12 Več Kornelija Ajlec, Odnosi med begunci iz Jugoslavije in Unrro v Egiptu v letih 1943-1946: doktorska disertacija (Ljubljana: Filozofska fakulteta, 2013).

13 Kornelija Ajlec, »Jugoslovanski begunci v Egiptu in njihova politična opredeljenost 1943-1946, « Zgodovinski časopis 67, št. 3-4 (2013): 147-62.

14 Charles R. S. Harris, Allied Military Administration of Italy 1943-1945 (London: Her Majesties Stationary Office, 1957), 439. 
razseljenih oseb, ki so podpirale novo komunistično vlado, se je vrnil v Jugoslavijo že $\mathrm{v}$ prvih mesecih po osvoboditvi. V predele južnega Jadrana so se begunci vračali že jeseni in pozimi leta 1944, v preostale dele države pa spomladi in poleti 1945. Politično nevtralni ali odkriti podporniki begunske vlade so se spoprijemali z resnimi dilemami, ki so bile ključne za njihovo prihodnost; ali naj se vrnejo v Jugoslavijo in se soočijo s preganjanjem zaradi svoje podpore kralju ter splošnim pomanjkanjem. ${ }^{15}$

Vodstvo nove komunistične jugoslovanske vlade je dalo omahujočim beguncem jasno vedeti, da se morajo vrniti v domovino $\mathrm{z}$ evakuacijskimi konvoji, saj se kasneje morda ne bodo smeli nikoli več vrniti v Jugoslavijo. ${ }^{16}$ Unrrini dokumenti omenjajo, da je Jugoslavija dala beguncem ultimat za vrnitev do 15 . januarja 1945, sicer je obstajala nevarnost, da bodo izgubili državljanstvo. ${ }^{17}$ Ta datum so kasneje sicer prestavili, saj se je zadnji konvoj na dalmatinsko obalo vrnil skoraj dva meseca po omenjenem datumu. Je pa vlada Federativne ljudske republike Jugoslavije (FLRJ) leta 1946 sprejela Zakon o prenosu sovražnikovega premoženja $v$ državno last in o sekvestaciji premoženja odsotnih oseb, ki je v 2. členu eksplicitno navajal, da se »premoženje državljanov FLRJ, ki bivajo $\mathrm{v}$ inozemstvu, pa se niso odzvali pozivu, naj se vrnejo v domovino v roku, ki ga določa zakon / ... / sme do odločbe o zaplembi / ... / dati pod sekvester države ali zanj uporabiti kako drugo sredstvo zavarovanja po zakonu o zaplembi in o izvajanju zaplembe «. Edina izjema, ki jo je zakon v tem členu dovoljeval, je bil prenos dela premoženja v last bližnjega sorodstva, v obsegu, ki je »zadoščal za primerno preživetje $\ll{ }^{18}$ Izguba imetja in kmalu zatem tudi državljanstva sta bila torej zadostna razloga, da se je večina preostalih razseljenih oseb v Italiji končno odločila emigrirati v tretje države.

Dokler pa njihova emigracija ni bila urejena, so bili še naprej v oskrbi zaveznikov, ki so ponovno odprli vprašanje skrbi za razseljene osebe. Unrrina italijanska misija je pričakovala, da bo morala po uradnemu začetku svojega delovanja marca 1945 prevzeti skrb za tiste razseljene osebe, ki se ne bodo želele vrniti v domovino. Iz internega memoranduma je razvidno, da so že decembra 1944 predlagali pripravo načrta preskrbe teh oseb. Jugoslovanske razseljene osebe so razdelili v tri skupine: na tiste, ki so zapustile Jugoslavijo zaradi nestrinjanja z novo politično ureditvijo, na nekdanje pripadnike kraljeve vojske in na jugoslovanske Jude, ki naj bi jih bilo takrat v Santa Marii al Bagno med 500 in 600. Vojska je predlagala, da za vse skupine še naprej skrbijo v okviru taborišč. ${ }^{19}$ Predstavniki Unrre so se skušali pri postopanju z rojalističnimi in neopredeljenimi razseljenimi osebami v večji meri zaščititi pri nadrejenih $\mathrm{v}$ Washingtonu. Obča politična situacija je bila namreč vedno bolj zapletena, prepad med jugoslovanskimi političnimi strujami pa vedno globlji.

15 Pomanjkanje je bilo del evropskega povojnega vsakdanjika, vendar so bili nekateri predeli Jugoslavije še posebej hudo prizadeti. Jugoslavija je tako postala ena izmed večjih prejemnic Unrrine pomoči. Več o gospodarskem stanju v Jugoslaviji in Unrrini pomoči v Ajlec, UNRRA and Its Arrival in Yugoslavia, 1944-1945. Kornelija Ajlec, UNRRA v Jugoslaviji in Sloveniji, Prispevki za novejšo zgodovino 53, št. 2 (2013): 79-99.

16 Howard Wriggins, Picking up the Pieces from Portugal to Palestine. Quaker Refugee Relief in World War II. A Memoir (Lanham: University Press of America, 2004), 102.

17 UNA, IM, S-1459-0000-0098, Yugoslav Displaced Persons 1944-1949, UNRRA Inter-Office Memo, 21 12. 1944.

18 Uradni list FLRJ, št. 63, 6. 8. 1946, 749, 750.

19 UNA, IM, S-1459-0000-0098, Yugoslav Displaced Persons 1944-1949, UNRRA Inter-Office memo, 21. 12. 1944. 


\section{Dodeljevanje finančne pomoči}

Okoli 3.000 jugoslovanskih državljanov je $\mathrm{v}$ tem času živelo izven taborišč. Med njimi jih je 2.500 potrebovalo finančno pomoč. Vendar pa je marca 1945 od Zavezniške finančne agencije (Allied Financial Agency) to pomoč v Italiji dobivalo le 44 Jugoslovanov. Preostali pomoči potrebni niso prejeli nikakršne pomoči od novembra 1944 naprej, ko je prenehala delovati t. i. »jugoslovanska kraljeva misija « (Royal Yugoslav Mission). Tudi zaradi nenadnega izpada finančne pomoči so zavezniki ustanovili Zavezniško finančno agencijo, da bi pomagali vsem razseljenim državljanom zavezniških držav. Pomoč so delili s pomočjo vladnih delegatov v zavezniškem Posvetovalnem svetu za Italijo (Advisory Council for Italy). V svetu so bili predstavniki tistih narodov, katerih državljani so se nahajali v Italiji kot begunci. Posvetovalni svet za Italijo je tesno sodeloval tudi z Unrro, sicer pa je deloval pod okriljem Zavezniškega nadzornega sveta. Nova jugoslovanska vlada je v svet imenovala dr. Slovena Smodlako. Ta je vsak mesec odobril spisek državljanov, za katere je menil, da potrebujejo pomoč, in višino zneska, ki so jim ga podelili. Zavezniški nadzorni svet je nato poskrbel za izplačilo pomoči preko Banke Italije (Bank of Italy), prejemniki pa so se ob prejemu pomoči s podpisom zavezali, da bodo znesek nekoč tudi vrnili. Porok za povračilo denarja je bila jugoslovanska vlada, zato je imela tudi pravico, da je zavrnila prosilce za pomoč. Ker pa je Smodlako nastavila nova vlada, so se v Unrri zbali, da bo ta odobril podporo le tistim posameznikom, ki so podpirali novo vlado. Vsi sumi Unrrinih predstavnikov so dejansko temeljili na precej resnih indicih. Jugoslovanska delegacija v Bariju je namreč januarja 1945 odobrila le 15 odstotkov količine mesečnih podpor beguncem kot mesec poprej. Še več, v memorandumu so zapisali, da do podpore niso upravičeni: ${ }^{20}$

1. zdravi moški, ki so zmožni služenja vojske, a so se uprli služenju v NOVJ;

2. osebe, ki so zavrnile možnost, da bi se vrnile v Jugoslavijo.

Poleg tega je Smodlaka vedno znova ponavljal stališče nove jugoslovanske vlade, da je predstavnik vseh Jugoslovanov v Italiji, čeprav so podporniki kralja in njegove vlade izjavili, da v državi ni več njihovega predstavnika. Če bi obveljala trditev razseljenih oseb, bi to pomenilo, da bi odločbe za podporo začeli dobivati od zaveznikov. IGCR je namreč pooblastil zavezniško poveljstvo, da lahko samo dodeli pomoč tistim, za katere meni, da jo potrebujejo, vendar nimajo svojega predstavnika v Italiji. Ker pa je bila nova povojna jugoslovanska vlada mednarodno priznana predstavnica Jugoslavije, zavezniki tega pooblastila niso mogli uveljaviti, Smodlaka pa je imel še naprej diskrecijsko pravico pri dodeljevanju podpor. V nasprotju s pooblastilom IGCR pa se je UNRRA zavezala, da bo pomagala vsem državljanom držav zaveznic, ne glede na njihovo politično zavezo ali druge okoliščine. $\mathrm{V}$ to zavezo so bili vključeni tudi tisti Jugoslovani, ki jim je jugoslovanski delegat odrekel pomoč. A še preden so lahko Unrrini predstavniki nacionalnim delegatom predstavili Unrrin načrt, je Smodlaka 18. marca $1944 \mathrm{v}$ pismu direktorju Unrrine italijanske misije S[purgeonu] $\mathrm{M}$ [iltonu]

20 UNA, IM, S-1459-0000-0098, Yugoslav Displaced Persons 1944-1949, Financial Assistance for Yugoslavs. Confidential, 13. 1. 1945. 
Keenyju prvič zapisal, da UNRRA ne sme dajati pomoči nobenemu jugoslovanskemu državljanu brez njegove izrecne privolitve. Keeny se je po tem strogo izraženem stališču podal na diplomatsko misijo, da bi čim prej razrešili to vprašanje. Po nasvet se je obrnil na direktorja Unrrine Evropske regionalne pisarne (European Regional Office) Roberta G. A. Jacksona, na osebnega predstavnika generalnega direktorja Unrre (Personal representative of the Director General) Roya Hedricksona in na načelnika Pisarne za evropske misije (Office of European Mission Affairs) Georga Xanthakyja. Na skupnem sestanku 1. aprila 1945 so se dogovorili, da bodo z nastalo situacijo seznanili sedež Unrre v Washingtonu in direktorja Unrrine jugoslovanske misije Mihaila Sergejčika. Istočasno so seznanili tudi ameriškega in britanskega veleposlanika v Italiji Alexandra Kirka in sira Noela Charlesa, v upanju, da bosta osebno posredovala pri Smodlaki in ga zaprosila, da umakne stališča, izrečena v pismu 18. marca. Vendar pa je veleposlanik Kirk obvestil Keenyja, da pri Smodlaki ne bo interveniral in da naj vsa pogajanja tečejo preko Unrrinega direktorata v Washingtonu. ${ }^{21}$

Smodlaka se je odločno uprl vsem poskusom italijanske misije, da bi nediskriminatorno pomagala vsem Jugoslovanom. V pismu Keenyju 2. aprila 1945 je ponovil, da UNRRA glede jugoslovanskih beguncev ne sme delovati brez njegovega privoljenja, torej privoljenja jugoslovanskega delegata. ${ }^{22} \mathrm{~A}$ še istega dne je Keeny dobil obvestilo glavnega poverjenika Zavezniškega nadzornega sveta, ki je Smodlaki sporočil, da mora vrhovno poveljstvo pomagati vsem jugoslovanskim državljanom, saj se od njega terja netoleranca do diskriminacije na podlagi politične pripadnosti. ${ }^{23}$ Keenyju je izrekel podporo tudi direktor Unrrine evropske regionalne pisarne, Roy Hendrickson. V pismu je dal prednost Unrrinemu poslanstvu glede nudenja pomoči vsem razseljencem, ki so državljani držav Združenih narodov, torej zaveznic, med katerimi je tudi Jugoslavija. Pri tem je Hendrickson izrecno poudaril, da je UNRRA dolžna poskrbeti tudi za vse tiste, za katere glede na njene sporazume sicer ni pooblaščena skrbeti. Pri kršitvi sporazumov je Hendrickson naložil Keenyju, naj smatra tiste begunce oz. razseljene osebe, ki jim lastna država odreče preskrbo, kot osebe brez države. To je pomenilo, da jih je UNRRA smatrala kot apatride, za katere pa je bila pooblaščena skrbeti. Poudaril je še, da mora UNRRA iz humanitarnih razlogov občasno prekršiti nekatere sporazume, vsaj dokler se ne razjasni status teh razseljenih oseb. ${ }^{24}$ Kako se je cela situacija s podeljevanjem podpore zaključila, iz zbranih dokumentov žal ni znano. Očitno pa je UNRRA uveljavila Hendricksonov napotek in poskrbela za preskrbo vseh razseljenih oseb - tistih, ki so bile še vedno nastanjene v taboriščih, in tudi tistih, ki so živele izven taborišč. Je pa morala pri uveljavljanju humanitarne pomoči jugoslovanskim razseljenim osebam v Italiji postopati zelo previdno, saj ni smelo priti do

21 UNA, IM, S-1459-0000-0098, Yugoslav Displaced Persons 1944-1949, Memorandum on the Yugoslav Situation in Italy, 6. 4. 1945, 1-3.

22 UNA, IM, S-1459-0000-0098, Yugoslav Displaced Persons 1944-1949, Pismo Slovena Smodlake direktorju Unrrine italijanske misije S. M. Keenyju, 2. 4. 1945.

23 UNA, IM, S-1459-0000-0098, Yugoslav Displaced Persons 1944-1949, Memorandum on the Yugoslav Situation in Italy, 6. 4. 1945, 3.

24 UNA, IM, S-1459-0000-0098, Yugoslav Displaced Persons 1944-1949, Jugoslav D.Ps, Pismo Hendricksona Keenyju, 5. 4. 1945. 
večjega konflikta med Unrro in jugoslovansko vlado. Če bi se odnosi med organizacijo in Jugoslavijo zaostrili, bi lahko jugoslovanska vlada otežila delo Unrrine jugoslovanske misije, kar bi imelo katastrofalne humanitarne posledice v Jugoslaviji. ${ }^{25}$ UNRRA je morala biti čim bolj taktna in diplomatska.

Nesoglasja pa se niso vrstila le na terenu v Italiji, kjer je jugoslovanska vlada $\mathrm{z}$ metodami, ki jih je uporabljal dr. Smodlaka, poskušala prisiliti jugoslovanske razseljene osebe, da bi se vrnile v domovino. Vrnitev jugoslovanskih razseljenih oseb je skušala doseči tudi na najvišji ravni diplomacije. Na zasedanju posebnega komiteja za begunce in razseljene osebe (Special Committee on Refugees and Displaced Persons) Organizacije združenih narodov (OZN) 8. februarja 1946 je jugoslovanski predstavnik dr. Aleš Bebler zahteval, da OZN prepove vso propagando v taboriščih pod neposredno upravo organizacije in njenih članic - torej tudi Unrre -, da naj se razseljene osebe ne vračajo v domovino. Ob predlogu je napadel tudi uprave begunskih taborišč v Nemčiji, Avstriji in Italiji, ${ }^{26}$ saj naj bi v njih taboriščno osebje s fizično silo preprečevalo repatriacijo razseljenih oseb. V pisnem odgovoru je takratni direktor Unrre, Herbert Lehman, zavrnil vse obtožbe dr. Beblerja in pojasnil, da 22 izmed 30 taborišč, ki jih je dr. Bebler omenjal v govoru, sploh ne obstaja. Hkrati pa je pojasnil, da je UNRRA v ostalih taboriščih dejansko delila informacije o političnem stanju in stanju preskrbe $\mathrm{v}$ izvornih državah razseljenih oseb, da so se te lahko samostojno in po svoji volji odločale za repatriacijo ali emigracijo v tretje države. Predlog dr. Beblerja je izzval široko in več dni dolgo debato o individualni svobodi odločanja razseljenih oseb. $V$ debati sta se med drugim aktivno opredelila predstavnik Sovjetske zveze Amazasp Arutiunian in Eleanor Roosevelt, ki je predsedovala Komisiji OZN za clovekove pravice. Sovjetski predstavnik se je postavil na stran Jugoslavije in predlagal, da bi bila edina dovoljena propaganda tista, ki prihaja iz izvornih držav. Eleanor Roosevelt pa je zagovarjala čim bolj široko informiranost in stopnjo individualnega odločanja. Predlog Jugoslavije je bil nazadnje zavrnjen, komite pa je Generalni skupščini OZN predlagal, da se zavzema za svobodno odločanje razseljenih oseb glede repatriacije. ${ }^{27}$

\section{Nov val razseljenih oseb}

V letu 1946 se je število jugoslovanskih razseljenih oseb v Italiji še povečalo, saj je bilo število prebežnikov čez jugoslovansko-italijansko mejo vedno večje. Kot poročajo Unrrini dokumenti, je šlo večinoma za prebežnike srednjega in višjega sloja trgovce in obrtnike ter bogatejše kmete, ki so nasprotovali novi politični ureditvi $\mathrm{v}$ Jugoslaviji. ${ }^{28}$ Statistike so Jugoslovane v oskrbi zaveznikov zdaj delile na naslednje tri

25 UNA, IM, S-1461-0000-0027, Cables - to and from Yugoslavia Mission 1944-1949, Telegram jugoslovanske misije italijanski misiji, 9. 5. 1945.

26 Pridobljeni viri žal ne ponujajo poimenskega spiska taborišč.

27 Vernant, The Refugee in the Post-War World, 71, 72, 76.

28 UNA, IM, S-1479-0000-0009, DP Operations (Italy) - A. C. Correspondence 1944-1949, Poročilo o stanju beguncev v Italiji, april 1946, 2. 
skupine: begunce v oskrbi Unrre, begunce v oskrbi Zavezniškega nadzornega sveta in Jugoslovane v oskrbi vrhovnega poveljstva zavezniških sil (AFHQ). Marca 1946 je bilo skupno število beguncevv vseh treh skupinah 6.586. Od tega je bilo 1.829 Srbov, 2.747 Hrvatov in 2.010 Slovencev. Število novih pribežnikov čez jugoslovansko-italijansko mejo je bilo vedno večje, število razseljenih oseb pa je še naprej naraščalo. Zgovorna statistika je bila narejena za mesec oktober $1946:{ }^{29}$

\begin{tabular}{|c|c|c|c|}
\hline \multicolumn{4}{|c|}{ Jugoslovanske razseljene osebe v oskrbi Unrre } \\
\hline \multicolumn{2}{|l|}{ Judi } & \multicolumn{2}{|c|}{ Ostali Jugoslovani } \\
\hline Taborišča & 350 & Taborišča & 455 \\
\hline Hachsharoth $^{31}$ & 59 & & \\
\hline $\begin{array}{l}\text { Dobitniki pomoči } \\
\text { izven taborišč }\end{array}$ & 411 & $\begin{array}{l}\text { Dobitniki pomoči } \\
\text { izven taborišč }\end{array}$ & 806 \\
\hline Skupaj & 820 & Skupaj & 1.261 \\
\hline & Skupaj & 2.081 & \\
\hline
\end{tabular}

\begin{tabular}{|c|c|}
\hline \multicolumn{2}{|c|}{$\begin{array}{l}\text { Jugoslovanske razseljene osebe v oskrbi Zavezniškega nadzornega sveta (Allied } \\
\text { Commission) }\end{array}$} \\
\hline Judi & 85 \\
\hline Ostali Jugoslovani & 6.750 \\
\hline Skupaj & 6.835 \\
\hline
\end{tabular}

\begin{tabular}{|l|c|}
\hline \multicolumn{2}{|c|}{$\begin{array}{c}\text { Jugoslovanske razseljene osebe v oskrbi Vrhovnega poveljstva zavezniških sil } \\
\text { (Allied Force Headquarters - AFHQ) }\end{array}$} \\
\hline Vojaki sovražnika, ki so se predali & 622 \\
\hline
\end{tabular}

Skupaj je bilo takrat v Italiji 9.538 jugoslovanskih razseljenih oseb, za katere so skrbeli zavezniki in ki se načeloma niso vrnile v Jugoslavijo. Unrrino poročilo ocenjuje, da so zavezniki zanje dobro skrbeli in da so bile celo bolje preskrbljene kot večina domačinov v tistem času. A v številčnem popisu so omenjene le tiste, za katere so zavezniki neposredno odgovarjali in jim nudili preskrbo. Vojaške oblasti so namreč ocenjevale, da se je v Italiji v tem obdobju nahajalo med 45.000 in 55.000 Jugoslovanov, med

29 UNA, IM, S-1459-0000-0011, D.P's. Information concerning Jugoslav D.Ps in Italy, 9. 11. 1946.

30 Pred drugo svetovno vojno so bili hachsharothi centri, v katerih so se Judi izobraževali za pretežno obrtniške poklice. Kot je zapisano v poročilu izbraževalne judovske organizacije ORT iz leta 1947, pa hachsharothi v povojni Italiji niso izobraževali, razen dveh ribiških tečajev. Pretežno je bilo v njih najti rokodelce, ki so delali v dobro judovske skupnosti. Več Report on the ORT Activities, August 1946-July 1947 (Paris, Geneva: ORT Union, 1947), 53, dostopno na: dpcamps.ort.org: https://dpcamps.ort.org/fileadmin/image_archive/reports/ort\%20italy\%20report.pdf, pridobljeno avgusta 2020.

31 Število predanih vojakov, za katere je skrbel AFHQ, se je v oktobru 1946 precej znižalo v primerjavi z nekaj meseci pred tem. Takrat je AFHQ skrbel za približno 7.000 predanih vojakov, ki pa jih je nato vojska mobilizirala za prevzem služb, ki so jih pred tem opravljali vojaki 2. poljskega korpusa. Mobiliziranci so službe opravljali v uniformah, vendar neoboroženi. 
njimi pa jih je približno 3.000 našlo službo v zavezniški vojski, a zanje zavezniške enote načeloma niso skrbele humanitarno, saj so za svoje delo prejemali plačo. Med 5.000 in 10.000 Jugoslovanov v Italiji naj bi se preživljalo s preprodajo na črnem trgu in drugačnim kriminalom, kar naj bi jim omogočalo precej boljši standard, kot je bilo takrat povprečje $\mathrm{v}$ državi. ${ }^{32} \mathrm{~V}$ tem obdobju je sicer že začel naraščati odpor Italijanov do tujcev na svojem ozemlju. Posledično je veliko novih prebežnikov iz Jugoslavije ponovno iskala zavetje $\mathrm{v}$ Unrrinih in zavezniških taboriščih. Ne le da na tak način prebežnikom ni bilo treba najti službe, ki so bile že tako ali tako precej redke, temveč so si tako tudi olajšali možnost emigracije v tretje države. Preiskava AFHQje tako pokazala, da se je med julijem in novembrom $1946 \mathrm{v}$ taborišča ilegalno pretihotapilo okoli 600 Jugoslovanov. Zato so zavezniki začeli zaostrovati pogoje za sprejem. Med drugim je bilo zdaj obvezno tudi posedovanje izkaznice razseljene osebe ali drugega dokazila, s katerim so prosilci za sprejem dokazali, da so bili begunci že pred 8. majem $1945 .{ }^{33}$

\section{Pot v domovino}

$\mathrm{Na}$ koncu še nekaj besed o nadaljnji repatriaciji. Vodja italijanske misije Keeny v poročilu poroča, da je UNRRA v sodelovanju z jugoslovansko vlado še vedno vodila programe repatriacije. Za vrnitev v domovino so se Jugoslovani sicer redko odločali, kljub temu pa prisiljene repatriacije ni bilo. ${ }^{34} \mathrm{~V}$ več Unrrinih dokumentih je mogoče slediti postopku repatriacije od začetka leta 1946 pa do konca leta 1947, a po opisu so si med seboj vsi enaki. Najbolj izčrpno poročilo je nastalo 16. maja 1946, navaja pa, da sta pri postopku repatriacije sodelovala urad za pomoč (Bureau of Relief Service) Unrrine italijanske misije in jugoslovanski urad za repatriacijo, ki je sprva deloval v okviru jugoslovanskega ministrstva za socialo, kasneje pa ministrstva za notranje zadeve. Poročilo spremlja skupino dvajsetih repatriirancev, ki so 25. aprila 1946 začeli svojo skupno pot proti domovini iz taborišča Cinecitta. Do tja so verjetno prispeli iz drugih taborišč v južni in osrednji Italiji. Iz Rima so odpotovali v Trst, kamor so prispeli 31. aprila. Tu so jih nastanili v taborišču 13. korpusa zavezniške vojaške oblasti v coni A Julijske krajine. 2. maja pa so se v spremstvu osebja jugoslovanskega Rdečega križa vkrcali na vlak in pri Sežani prečkali Morganovo linijo. Neposredno po prihodu vlaka v Divačo so se izkrcali in bili predani osebju jugoslovanskega urada za repatriacijo. Nastanili so jih $\mathrm{v} \gg$ prehodno taborišče « oziroma v trinadstropno stavbo, nekaj sto metrov oddaljeno od železniške postaje $\mathrm{v}$ Divači, $\mathrm{v}$ katero so lahko sicer nastanili do 100 ljudi. Če je kateri konvoj sestavljalo več kot 100 repatriirancev, so celo skupino takoj prepeljali $v$ »repatriacijsko taborišče « v Ljubljani. V prvo ali drugo taborišče naj bi naseljevali predvsem repatriirance iz bolj oddaljenih republik Jugoslavije in drugih

32 UNA, IM, S-1459-0000-0011, D.P's. Information concerning Jugoslav D.Ps in Italy, 9. 11. 1946.

33 UNA, IM, S-1479-0000-0010, DP Operations (Italy) - Allied Commission - Special Orders - Daily Bulletins Instructions 1944-1949, Yugoslav Refugees desiring admission into Allied Commission D.P. Centers, 12. 11. 1946. 34 Ibid. 
držav, ki so čakali nadaljnji transport proti domu, medtem ko so repatriirance iz cone B Julijske krajine, Slovenije in Hrvaške že drugi dan ali v nekaj dneh poslali domov. Vsekakor pa nobenega konvoja repatriirancev niso zadrževali v Divači dlje kot dva dni. ${ }^{35}$ Poročilo nadalje podaja nekatere izjave repatriirancev, ki govorijo, da so se bali vrnitve v domovino. Poudarili so, da so jih pred vrnitvijo mnogi svarili, a da slabih izkušenj niso imeli. Pri tem pa je treba opozoriti, da so intervjuji s piscem poročila nastali največ šest tednov po prihodu repatriirancev in da so bili repatriiranci zelo verjetno zaslišani bodisi ob prihodu v Divačo bodisi kdaj kasneje po prihodu domov.

Kljub vsemu pa se je po začetnem valu v letih 1944 in 1945 le malo jugoslovanskih razseljenih oseb vrnilo v domovino. Ostali Jugoslovani so ostajali v taboriščih, ki jih je po ukinitvi Unrre junija 1947 prevzela Mednarodna begunska organizacija (IRO). Od tu so Jugoslovanom urejali sprejem v tretje države, toda postopki so bili mnogokrat dolgotrajni, saj so zadnje jugoslovanske razseljene osebe zapustile Italijo šele ob koncu 50. let.

\section{Viri in literatura}

\section{Arhivski viri}

- UNA, United Nations Archives and Records Managment Section - Arhiv organizacije združenih narodov, New York City:

- Fond Unrrine Italijanske misije (IM) (AG-018-009), Chief of Mission (S-1459), Chief of Mission - Office of the Special Assistant to the Chief of Mission for Government Liasion (S1461), Bureau of Relief Services (S-1479)

\section{Literatura}

- Ajlec, Kornelija. »Jugoslovanski begunci v Egiptu in njihova politična opredeljenost 1943-1946.« Zgodovinski časopis 67, št. 3-4, (2013): 428-48.

- Ajlec, Kornelija. »UNRRA and Its Arrival in Yugoslavia, 1944-1945.« Istorija 20. veka, št. 2 (2020): 129-50.

- Ajlec, Kornelija. »UNRRA v Jugoslaviji in Sloveniji.« Prispevki za novejšo zgodovino 53, št. 2 (2013): 79-99.

- Ajlec, Kornelija. Odnosi med begunci iz Jugoslavije in Unrro v Egiptu v letih 1943-1946: doktorska disertacija. Ljubljana, 2013.

- Čepič, Tatjana. »Oris poteka repatriacije v letu 1945.« Kronika 33, št. 2-3, (1985): 232-36.

- Gombač, Jure. »K politiki povratnih migracij po drugi svetovni vojni.« V: Marina Lukšič Hacin, ur. Spet doma? Povratne migracije med politiko, prakso in teorijo, Ljubljana: Založba ZRC, 2006, 13-57.

- Harris, Charles R. S.. Allied Military Administration of Italy 1943-1945. London: Her Majesties Stationary Office, 1957.

35 UNA, IM, S-1479-0000-0154, Camps Administration - Emigration 1944-1949, Priveredbe o metodama primanja i brizi koju o repatriaciji vode Jugoslavenske vlasti, 16. 5. 1946. 
- Landau, Ronnie S.. The Nazi Holocaust. It's History and Meaning. New York: I.B Tauris, 2006.

- Proudfoot, Malcolm J.. European Refugees 1939-1952. A Study in Forced Population Movement. Evanston: Northwestern University Press, 1956.

- Vernant, Jacques. The Refugee in the Post-War World. New Haven: Yale University Press, 1956.

- Woodbridge, George. UNRRA. The History of the United Nations Relief and Rehabilitation Administration. Vol. 3. New York: Columbia University Press, 1950.

- Wriggins, Howard. Picking up the Pieces from Portugal to Palastine. Quaker Refugee Relief in World War II. A Memoir. Lanham: University Press of America, 2004.

- Wyman, Mark. DPs. Europe's Displaced Persons, 1945-51. Ithaca, Cornell: University Press, 1998.

\section{Spletni viri}

- A Ccomplilation of the Resolutions on Policy. First and Second Sessions of the UNRRA Council. Volume 2, Resolutions on Policy, 21-23. Washington D.C: United Nations Relief and Rehabilitation Administration, 1944. Dostopno na: Hathitrust.org: https://hdl.handle.net/2027/ mdp.39015063799061. Pridobljeno: avgust 2020.

- Report on the ORT Activities, August 1946-July 1947, 53. Paris, Geneva: ORT Union, 1947. Dostopno na: dpcamps.ort.org: https://dpcamps.ort.org/fileadmin/image_archive/reports/ort \%20italy\%20report.pdf. Pridobljeno: avgust 2020.

- Proceedings of the Intergovernmental Committee, Evian, July 6th to 15th, 1938 ... Record of the Plenary Meetings of the Committee. Resolutions and Reports. London, 1938. Yad Vashem The World Holocaust Remembrance Center. Dostopno na: https://www.yadvashem.org/docs/evian-conference-decisions.html. Pridobljeno: avgust 2020.

Tiskani viri

- Uradni list FLRJ, št. 68, 6. 8. 1946.

\section{Kornelija Ajlec}

\section{THE ROLE OF UNRRA IN SUPPLYING AND REPATRIATING THE YUGOSLAVIANS DISPLACED IN ITALY (1945-1947)}

\section{SUMMARY}

The displaced Yugoslavs in Italy included the liberated detainees, internees, and prisoners; those who had been forcedly mobilised into the Italian Army; military refugees; and post-war political refugees. They were initially supplied by the military authorities and later on by the UNRRA. The UNRRA representatives in Italy would often argue with the representatives of the new Yugoslav government regarding the provision of financial support to those displaced persons that lived outside of the refugee camps and did not support the new Yugoslav government. The disagreements expressed by the Yugoslav authorities were also evident at the sessions of the United 
Nations Committees and Boards. In the discussions about the communication of information to the displaced Yugoslavians, the United Nations sided with these people and rejected the Yugoslav proposal regarding the restriction of the information about the political situation in the homeland. Regardless of the disputes, the UNRRA maintained solid cooperation with the Yugoslav government in the organisation of repatriation convoys. 